\title{
Sugarcane crop efficiency in two growing seasons in São Paulo State, Brazil
}

\author{
Fábio Ricardo Marin(1), Maria Leonor Lopes-Assad(2), Eduardo Delgado Assad(1), Carlos Eduardo Vian(3) \\ and Marcelo Cabral Santos(3)
}

(1)Embrapa Informática Agropecuária, Caixa Postal 6041, CEP 13083-886 Campinas, SP, Brazil. E-mail: marin@cnptia.embrapa.br, assad@cnptia.embrapa.br (2)Universidade Federal de São Carlos, Centro de Ciências Agrárias, Rodovia Anhanguera, Km 174 , CEP $13600-970$ Araras, SP, Brazil. E-mail: assad@cca.ufscar.br ${ }^{(3)}$ Universidade de São Paulo, Escola Superior de Agricultura Luiz de Queiroz, Avenida Pádua Dias, no 11, CEP 13418-900 Piracicaba, SP, Brazil. E-mail: vian@esalq.usp.br, mcsantos@esalq.usp.br

\begin{abstract}
A conceptual framework for crop production efficiency was derived using thermodynamic efficiency concept, in order to generate a tool for performance evaluation of agricultural systems and to quantify the interference of determining factors on this performance. In Thermodynamics, efficiency is the ratio between the output and input of energy. To establish this relationship in agricultural systems, it was assumed that the input energy is represented by the attainable crop yield, as predicted through simulation models based on environmental variables. The method of FAO's agroecological zones was applied to the assessment of the attainable sugarcane yield, while Instituto Brasileiro de Geografia e Estatística (IBGE) data were used as observed yield. Sugarcane efficiency production in São Paulo state was evaluated in two growing seasons, and its correlation with some physical factors that regulate production was calculated. A strong relationship was identified between crop production efficiency and soil aptitude. This allowed inferring the effect of agribusiness factors on crop production efficiency. The relationships between production efficiency and climatic variables were also quantified and indicated that solar radiation, annual rainfall, water deficiency, and maximum air temperature are the main factors affecting the sugarcane production efficiency.

Index terms: Saccharum, pedological aptitude, geoprocessing, agrometeorological modeling.

\section{Eficiência da produção de cana-de-açúcar em duas safras no Estado de São Paulo}

Resumo - Um conceito de eficiência de produção agrícola foi derivado da Termodinâmica, para gerar um indicador para avaliação do desempenho de sistemas de produção agrícola e quantificação da interferência dos fatores determinantes desse desempenho. Em Termodinâmica, a eficiência de um processo é dada pela razão entre a energia recuperada e a energia utilizada. Para estabelecer essa relação em sistemas agrícolas, admitiu-se que a energia utilizada seja dada pela produtividade atingível, estimada por modelos de simulação desenvolvidos com base em variáveis ambientais. O método das zonas agroecológicas da FAO foi utilizado para a estimativa da produtividade atingível, e os dados do Instituto Brasileiro de Geografia e Estatística (IBGE), como produtividade observada. Avaliou-se a eficiência da produção de cana-de-açúcar no Estado de São Paulo, em duas safras, e calculou-se sua correlação com alguns fatores do meio físico que regulam a produção. Foi identificada forte relação da eficiência da produção agrícola com a aptidão agrícola do solo. Isto permitiu inferir sobre o efeito de fatores relativos ao agronegócio sobre a eficiência da produção agrícola. Foi possível identificar, ainda, que a radiação solar, a deficiência hídrica, a quantidade de chuva e a temperatura máxima são as principais variáveis climáticas que afetam a eficiência da produção agrícola.
\end{abstract}

Termos para indexação: Saccharum, aptidão pedológica, geoprocessamento, modelagem agrometeorológica.

\section{Introduction}

Agroecosystems can be thought of as machines that utilize solar energy to maintain composition and organization. From a thermodynamic standpoint, the efficiency of any process can be expressed as the ratio of energy output to energy input. This concept has been applied to analyze the energy flow in agroecosystems, since the 1970s (Monteith, 1977), and to analyze the relation between biomass chemical energy and incident solar radiation.
However, Monteith (1972) suggests that this approach could also be applied to elucidate the biophysical factors that affect crop yields at a local scale. Four basic factors may affect the regional agricultural development: physical processes, including regional pedoclimatic conditions; structural components, corresponding to the agricultural systems and management practices adopted; institutional effects, involving governmental actions affecting price, credit, commercialization, and incentives; and research and development, related to 
innovations to increase yield and solve problems that restrict agricultural-related activities.

Based on these factors, a hypothesis that can be postulated is that crop efficiency, as evaluated on a regional scale, could serve as a performance indicator of the farming development level. Furthermore, this spatial representation could facilitate the identification of the key factors that affect agricultural production and the viability of regional agribusinesses.

The efficiency of crop production can be assumed as the ratio between observed and attainable crop yield. In order to evaluate this tool effectiveness, the concept of agricultural efficiency was applied to study the sugarcane performance in the State of São Paulo, Brazil, the main region of this crop production, representing approximately $60 \%$ of the total Country's sugarcane production (IBGE, 2002). The importance of sugarcane as a crop has grown in recent years, due to its potential as a viable option for renewable and clean energy (Goldemberg, 2007), in the context of the global warming related to human activities (IPCC, 2007). In addition to such qualitative aspects, sugarcane has an important social and environmental role in the Brazilian agribusiness (Macedo, 2007) and has been cultivated for many years. The social and economic development of several countries has been based on sugarcane. The integration of crop growth simulation models into geographic information systems allows for agricultural production performances to be evaluated on a geographic scale, as well as for the diagnosis of inhibitory factors, in cases of low efficiency, or beneficial factors that determine high indices of efficiency.

The objective of this study was to determine the crop production efficiency as an indicator for the level of agricultural development for a particular system, by relating it to climate and soil parameters and inferring about how outside farm factors can affect field farm production.

\section{Materials and Methods}

Observed sugarcane yield (OY) data for each county in São Paulo State, Brazil, during the growing seasons of 1995/1996 and 2002/2003, were obtained from the Brazilian Institute of Geography and Statistics (IBGE). These growing seasons were selected because they represent two different economic conjunctures of the sugarcane agribusiness in Brazil. During the growing season of 1995/1996, Brazil experienced the effects caused by deregulation of the sugarcane sector. According to Shikida \& Bacha (1999), 1995 represented the end of the period known as deceleration and crisis of the Brazilian sugarcane agribusiness. The deregulation of sugarcane was completed during 2002/2003 (Marjotta-Maistro, 2002), and agribusiness adapted easily to this change with the economic promise of sugarcane crops, mainly due to the rise in bi-fuel vehicles in Brazil, as well as the growing international use of ethanol. Other critical differences between these two periods were the ethanol and gasoline price ratios, as discussed in Goldemberg (2007) and Macedo (2007).

To assess the potential yield (PY), without any restriction element, and the attainable water-limited yield (WLY) (Bowen \& Baethgen, 2002), the Doorenbos \& Kassam (1979) approach (Equation 1) was applied, based on meteorological data supplied by the Brazilian Agrometeorological Monitoring System (www.agritempo.gov.br). The data for each time series spanned from the beginning of September until the end of August for the next year, representing a typical late growing season. For the growing season of 1995/1996, 62 weather stations constituted the meteorological database, and for the growing season of 2002/2003, 37 composed the database. The crop coefficients were obtained in Doorembos \& Kassam (1979) by assuming a growing cycle of 12 months, taking into account the adjustments provided by Barbieri (1993) (Equation 2):

$$
1-\frac{\text { WLY }}{P Y}=\operatorname{Ky}\left(1-\frac{\text { ETa }}{\text { ETm }}\right)
$$

in which: Ky is a water deficit sensibility factor that ranges from 0.1 , during ripening, to 0.75 throughout vegetative development (Table 1). The actual crop evapotranspiration (ETa) was computed for a 10-day time step, using a crop water-balance simulation technique. The Kc coefficients and development stages used were described by Doorenbos \& Kassam (1979) (Table 1), and the available soil water was chosen according to Alvarez et al. (2000) and Smith et al. (2005). Reference evapotranspiration was estimated following Camargo et al. (1999).

$$
\mathrm{PY}=-6.2501+0.2187 \mathrm{~S}+0.3304 \mathrm{~T}
$$

in which: $\mathrm{T}$ is the mean air temperature $\left({ }^{\circ} \mathrm{C}\right)$ for 10 days; and $\mathrm{S}$ is the incident solar radiation $\left(\mathrm{MJ} \mathrm{m}^{-2} \mathrm{~d}^{-1}\right)$, which was computed as a function of air temperature, 
according to Meza \& Varas (2000) and Conceição \& Marin (2007).

Data points of WLY, with grids defined by meteorological station network, were applied to generate maps covering the State of São Paulo using the ordinary kriging method available in the geostatistical module of ArcGis 9.2. To obtain the information layer constituted by sugarcane crop efficiency, maps of OY, also interpolated by ordinary kriging, were divided by WLY maps, both with $900 \mathrm{~m}$ spatial resolution.

To check the influence of abiotic factors on sugarcane crop efficiency, two different statistical tests were applied. For soil, the Spearman rank correlation coefficient (Snedecor \& Cochran, 1982) was used to compare values of efficiency, for counties where meteorological stations were installed, using discrete classification values of soil aptitude for sugarcane, ranging from 1 to 5 following Brasil (1979) (Figure 1).

In order to assess the statistical relationship between climate and efficiency, the Pearson coefficient (Snedecor \& Cochran, 1982) was applied by comparing sugarcane efficiency against total annual rain, solar radiation, maximum and minimum temperatures, and total annual water deficit. All variables were tested at the county scale, in an attempt to normalize the number of observations for both growing seasons, and to minimize any interference on the coefficient.

\section{Results and Discussion}

Estimated WLY values ranged from 47 to $158 \mathrm{Mg} \mathrm{ha}^{-1}$, which is consistent with yield limits of sugarcane observed during experimental conditions, when all yield-reducing factors are controlled (Maule et al., 2001).

Throughout the period analyzed between the two growing seasons, increasings were observed as follows: an approximate $3 \%$ for OY; $17 \%$ in the cropped area; and $7 \%$ in the number of counties with

Table 1. Parameters used to model sugarcane development and yield, in 1995/1996 and 2002/2003, in the State of São Paulo, Brazil.

\begin{tabular}{lccc}
\hline Development stages & $\begin{array}{c}\text { Days after } \\
\text { September }\end{array}$ & $\begin{array}{c}\text { Kc coefficients } \\
\text { (dimensionless) }\end{array}$ & $\begin{array}{c}\text { Available Soil } \\
\text { water (mm) }\end{array}$ \\
\hline Planting to 0.25 full canopy & 30 & 0.5 & 50 \\
0.25 to 0.75 full canopy & 150 & 0.8 & 70 \\
0.75 to full canopy & 300 & 1.1 & 100 \\
Ripening & 360 & 1.0 & 100 \\
\hline
\end{tabular}

economic sugarcane production, mainly in the West and Northwest regions (Figure 2), replacing what was originally pastureland (Macedo, 2007).

Mean values of efficiency ranged from 0.387 to 0.433 , between $1995 / 1996$ and $2002 / 2003$, which were mainly observed in the traditional sugarcane plantations of São Paulo, such as in Ribeirão Preto, Jaú, and Piracicaba. The major areas of sugarcane plantations had high quality agricultural soils such as Oxisols (Haplustox) (Brasil, 1979). In the West region, Figure 3 demonstrates that OY was lower in the central region because of the higher water deficits and soil types that cannot support the same yield level as those observed in the traditional sugarcane plantations. Koffler \& Donzeli (1987) claim that, despite the tolerance of sugarcane to soils with low fertility, soils with good physical and chemical conditions are essential for high yield levels.

The maps of sugarcane efficiency (Figure 3) indicate a rise in efficiency levels throughout the period, especially in traditional regions, where crop yield level increased above the overall average level of the State. This increase can be attributed to the adequate climate and soil conditions associated with an improvement in crop management support, due to the rise of sugarcane and gasoline prices (Goldemberg, 2007).

A high degree of dependence was identified between efficiency and soil aptitude variability, as indicated by the Spearman test. For the 2002/2003 growing season, the Spearman coefficient was 0.36 , indicating that $36 \%$ of crop efficiency was due to soil aptitude (Table 2). For the growing season of $1995 / 1996$, Spearman analysis explained $44 \%$ of the efficiency variation derived from

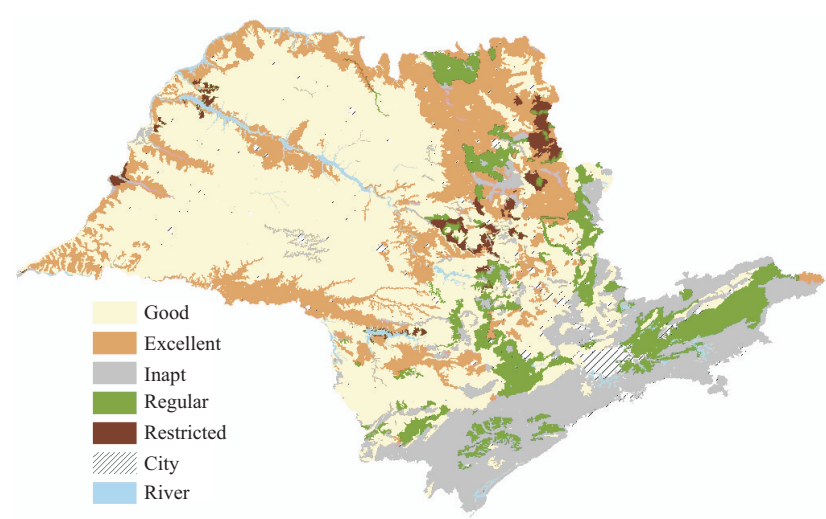

Figure 1. Soil aptitude map for agriculture, in the State of São Paulo, Brazil. Source: adapted from Oliveira (1999). 
soil characteristics. Although physical characteristics of soils could be assumed to be stable over time, fertility management can vary greatly in accordance with economic conjuncture and prices (Santos, 2005). Furthermore, sugarcane has demonstrated marked responses to higher quality management related to soil mineral nutrition (Kofler \& Donzeli, 1987). The difference between two Spearman coefficients indicates that sugarcane plantations respond more distinctly to soil aptitude, when other factors act on vegetative development and yield formation phases are controlled.

These data suggest that the ethanol conjuncture conditions, during the 2002/2003 growing season, were much more favorable than those observed in 1995/1996. Furthermore, this explains the heightened response to soil conditions during the first period, since fertilization can correct some nutritional limitations of soils and minimize the difference between soils. Brazil experienced the impact caused by the sugarcane sector deregulation during the 1995/1996 growing season (Goldemberg, 2007); and the agribusiness sector had already adapted and dealt with positive influences on sugarcane prices and commerce during the 2002/2003 period, as previously discussed. Other important differences between these two dates were the ethanol and gasoline price ratios, as discussed in Goldemberg (2007).
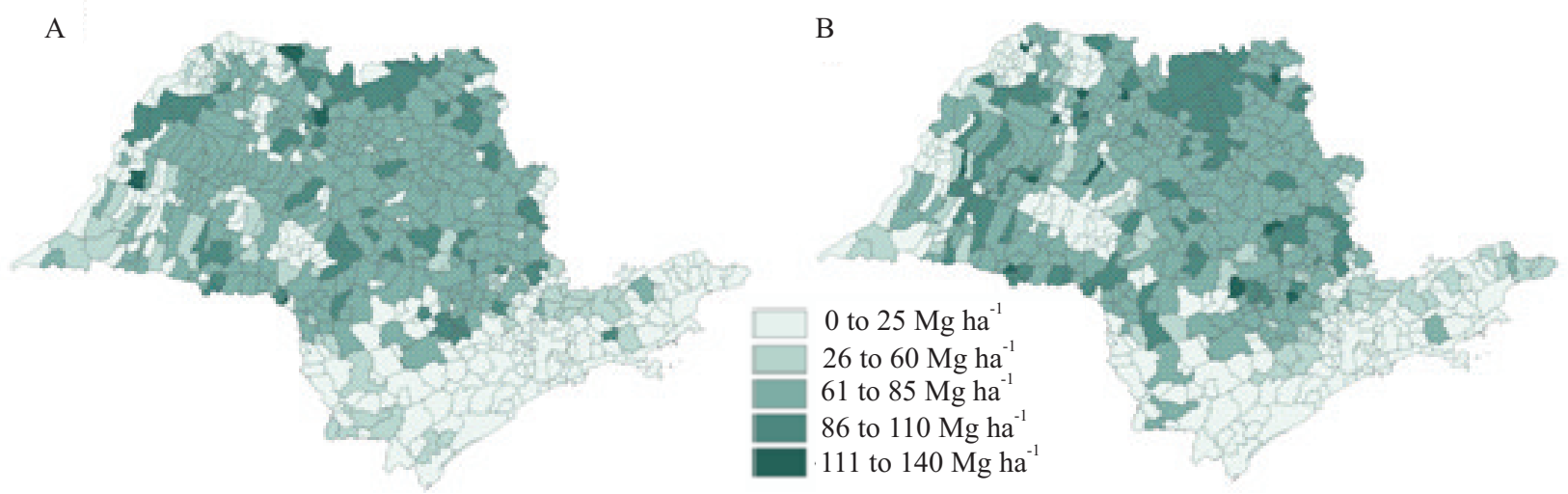

Figure 2. Spatial distribution of sugarcane production in the State of São Paulo, Brazil, during growing seasons of $1995 / 1996$ (A) and 2002/2003 (B). Source: IBGE (2002).
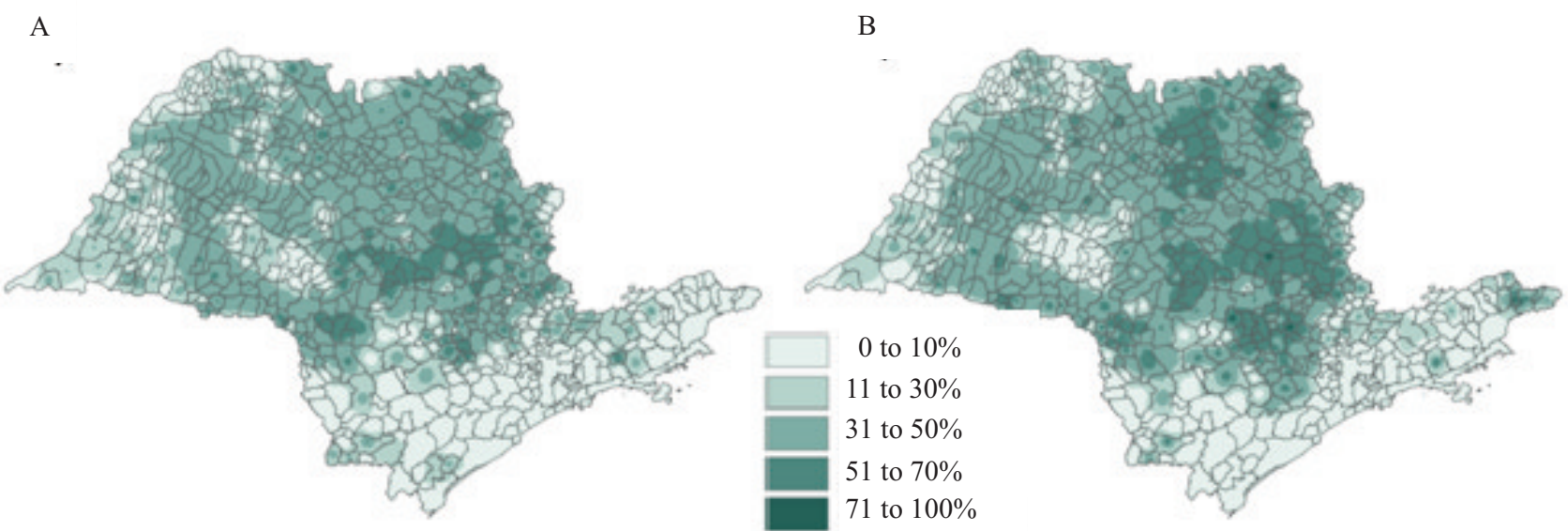

Figure 3. Spatial variation of sugarcane production efficiency, in the State of São Paulo, Brazil, during the growing seasons of 1995/1996 (A) and 2002/2003 (B). 
In an attempt to demonstrate that management can affect crop efficiency, considering all agriculture activities and not only sugarcane, it was observed that the total for simple fertilizer, acquired by final consumers in Brazil, was 10.8 million $\mathrm{Mg}$ during the growing season of 1995/1996, while it reached 22.8 million $\mathrm{Mg}$ in 2002/2003 (Brasil, 2005). Additionally, there was a significant rise in areas with efficiency above $70 \%$, from the 1995/1996 to the 2002/2003 growing season (Table 3), emphasizing the yield gain due to the improved scenarios for sugarcane agribusiness.

The production of ethanol-powered vehicles was strongly reduced in Brazil during the 1990s, and sugar prices were not high enough to support the sugarcane agribusiness with the same vigor as in the 1980s. After 2002 , this scenario was completely modified, due to: the high price of petroleum derived fuels; the rise in ethanol and sugar prices (Cezar, 1998); the advent of flex-fuel vehicles in Brazil; and to worldwide concerns regarding the environmental issues related to global warming (Kheshgi et al., 2000; Goldemberg, 2007).

Spearman coefficient variation also exemplifies how macroeconomic scenarios may affect the agriculture production, since the expectation for profit or loss is the main factor by which producers must plan and decide about their production system. Consequently, this has a major impact on crops occupying large areas and on the strategic importance of these crops use for food or bioenergy.

Table 2. Spearman coefficients, alongside the number of points used in the evaluations of soil variability aptitude of crop efficiency, during two sugarcane growing seasons, in the State of São Paulo, Brazil.

\begin{tabular}{lc}
\hline Growing season & Spearman coefficient \\
\hline $1995 / 1996$ & $0.44^{* *}$ \\
$2002 / 2003$ & $0.35^{* *}$ \\
\hline
\end{tabular}

**Significant at $1 \%$ probability.

Table 3. Area of efficiency classes of sugarcane crop production, during two growing seasons, in the State of São Paulo, Brazil.

\begin{tabular}{|c|c|c|c|c|}
\hline \multirow[t]{2}{*}{ Crop efficiency } & \multicolumn{2}{|c|}{$\begin{array}{c}\text { Growing season } \\
1995 / 1996\end{array}$} & \multicolumn{2}{|c|}{$\begin{array}{c}\text { Growing season } \\
2002 / 2003\end{array}$} \\
\hline & $\mathrm{km}^{2}$ & $\%$ & $\mathrm{~km}^{2}$ & $\%$ \\
\hline $0-10 \%$ & 59,285 & 24 & 55,855 & 22 \\
\hline $11-30 \%$ & 40,634 & 16 & 33,985 & 14 \\
\hline $31-50 \%$ & 42,648 & 17 & 35,185 & 14 \\
\hline $50-70 \%$ & 89,275 & 36 & 85,268 & 34 \\
\hline$>70 \%$ & 16,965 & 7 & 38,513 & 15 \\
\hline
\end{tabular}

Pearson coefficients, shown in Table 4, allow for the elucidation of how significantly the weather influences sugarcane efficiency in São Paulo State. Weather factors affected crop efficiency in the following order: solar radiation, annual accumulated water deficit (WD), maximum air temperature (Tmax), and minimum air temperature (Tmin).

In São Paulo State regions where sugarcane have been cultivated during the last 30 years are characterized by high quality environmental conditions regarding temperature and annual rainfall. Some recent studies have shown that sucrose accumulation in sugarcane stalks is a continuous process rather than a response to water deficiency or cold temperatures (Lisson, 2005). Thus, the strong correlation with solar radiation emphasizes that sugarcane yield has a close relationship with the absorption and use of radiation by canopy (Cheeroo-Nayamuth et al., 2000; Lisson, 2005).

Water deficits play an important role in activating sucrose accumulation, but they have a negative effect on crop growth (Keating et al., 1999; Cheeroo-Nayamuth et al., 2000). In the present study, however, since water deficits and solar radiation are positively correlated, the high WLY values were found in the region with high water deficits, explaining the positive Pearson coefficients observed (Table 5). However, it is reasonable to suppose that the same analysis would be made for the Central-West or Northeast regions of Brazil, where water deficits are higher, the Pearson coefficients would be negative due to WLY decrease .

Despite the effects caused by low temperatures, the correlation indexes obtained were below the expectation based on previous studies, which seems to be related to the narrow temperature range of main producer localities, in the State of São Paulo, since these areas do not experience the low temperature limits. As discussed for water deficit, the air temperature in the region showed a relatively small spatial variation,

Table 4. Pearson coefficients obtained for two growing seasons, by comparison of sugarcane crop efficiency with solar irradiance, minimum and maximum air temperatures, annual rainfall, and total annual water deficit.

\begin{tabular}{lccccc}
\hline $\begin{array}{l}\text { Growing } \\
\text { season }\end{array}$ & $\begin{array}{c}\text { Solar } \\
\text { irradiance }\end{array}$ & $\begin{array}{c}\text { Maximum } \\
\text { temp. }\end{array}$ & $\begin{array}{c}\text { Minimum } \\
\text { temp. }\end{array}$ & $\begin{array}{c}\text { Annual } \\
\text { rainfall }\end{array}$ & $\begin{array}{c}\text { Water } \\
\text { deficit }\end{array}$ \\
\hline $1995-96$ & $0.39 * *$ & $0.10^{* *}$ & $0.29 * *$ & $-0.25 * *$ & $0.31 * *$ \\
$2002-03$ & $0.22 * *$ & $0.07 * *$ & $0.17 * *$ & $-0.23 * *$ & $0.14 * *$ \\
\hline Mean & 0.31 & 0.09 & 0.23 & -0.24 & 0.23 \\
\hline
\end{tabular}

**Significant at $1 \%$ probability. 
Table 5. Mean and standard deviation values, over two growing seasons, for solar irradiance, minimum and maximum air temperatures, annual rainfall, and total annual water deficit.

\begin{tabular}{lrrrrr}
\hline Statistics & $\begin{array}{c}\text { Solar } \\
\text { irradiance }\end{array}$ & $\begin{array}{c}\text { Maximum } \\
\text { temp. }\end{array}$ & $\begin{array}{c}\text { Minimum } \\
\text { temp. }\end{array}$ & $\begin{array}{c}\text { Annual } \\
\text { rainfall }\end{array}$ & $\begin{array}{r}\text { Water } \\
\text { deficit }\end{array}$ \\
\hline Mean & 18.7 & 28.6 & 16.2 & $1,364.6$ & 324.0 \\
SD & 0.9 & 1.8 & 0.9 & 212.8 & 65.2 \\
\hline \multicolumn{5}{c}{ Growing season $2002 / 2003$} \\
Mean & 18.5 & 29.1 & 16.9 & $1,336.4$ & 358.4 \\
SD & 0.3 & 1.1 & 0.8 & 84.8 & 23.3 \\
\hline
\end{tabular}

and this may explain the weak relation with crop efficiency. In contrast, expanding the analysis for Southern region of Brazil, a higher correlation would be found for minimum temperature than it was for São Paulo, as base temperature can range from $8^{\circ} \mathrm{C}$ for node appearance (Campbell et al., 1998; Keating et al., 1999) to $18^{\circ} \mathrm{C}$ for other physiological processes (Lingle, 1999).

Despite the clear nature of this information, in zoning procedures, correlations indexes can give objective criteria, when considering the several environmental layers. Greater correlations were observed for soil classification and solar radiation, in both growing seasons, followed by accumulated annual rainfall and water deficits. This kind of information is important for indicating the main variable to be observed, when the research project's goal is to find areas where crop can reach maximum efficiency.

\section{Conclusions}

1. There is a marked difference in crop efficiency values between the two analyzed growing seasons, in the State of São Paulo, due to economical, agronomical, and industrial changes in the sugarcane agribusiness.

2. Sugarcane crop efficiency demonstrates a strong correlation with soil aptitude, for both growing seasons, followed by solar radiation, annual rainfall, and water deficits.

\section{References}

ALVAREZ, I.A.; CASTRO, P.R. de C. e; NOGUEIRA, M.C.S. Crescimento de raízes de cana crua e queimada em dois ciclos. Scientia Agricola, v.57, p.653-659, 2000.
BARBIERI, V. Condicionamento climático da produtividade potencial da cana-de-açúcar (Sacharum spp.): um modelo matemático-fisiológico de estimativa. 1993. 142p. Tese (Doutorado) - Universidade de São Paulo, Piracicaba.

BOWEN, W.T.; BAETHGEN, W.E. Simulation as a tool for improving nitrogen management. In: TSUJI, G.Y.; HOOGENBOOOM, G.; THORNTON, P.K. (Ed.). Understanding options for agricultural production. Dordrecht: Kluwer Academic Publishers, 2002. p.189-204.

BRASIL. Ministério da Agricultura. Aptidão agrícola das terras de São Paulo. Brasília: BINAGRI, 1979. 111p. (Estudos básicos para o planejamento agrícola. Aptidão Agrícola das Terras, 20).

BRASIL. Ministério da Agricultura, Pecuária e Abastecimento. Anuário da Agricultura Brasileira: 2005. Brasília: MAPA, 2005. Available at: $<\mathrm{http}: / /$ www.agricultura.gov.br/portal/page? pageid $=33,2789141 \&$ \& dad $=$ portal\&_schema $=$ PORTAL $>$. Accessed on: 29 Jan. 2008.

CAMARGO, A.P. de; MARIN, F.R.; SENTELHAS, P.C.; PICINI, A.G. Ajuste da equação de Thornthwaite para estimar a evapotranspiração em climas áridos e super-úmidos, com base na amplitude térmica diária. Revista Brasileira de Agrometeorologia, v.7, p.251-257, 1999.

CAMPBELL, J.A.; ROBERTSON, M.J.; GROF, C.P.L. Temperature effects on node appearance in sugarcane. Australian Journal of Plant Physiology, v.25, p.815-818, 1998.

CEZAR, S.A.G. Considerações sobre o papel dos preços e custos nas decisões de plantio no Estado de São Paulo. 1998. 101p. Tese (Doutorado) - Universidade de São Paulo, Piracicaba.

CHEEROO-NAYAMUTH,F.C.; ROBERTSON, M.J.;WEGENER, M.K.; NAYAMUTH, A.R.H. Using a simulation model to assess potential and attainable yield in Mauritius. Field Crops Research, v.66, p.225-243, 2000.

CONCEIÇÃO, M.A.F.; MARIN, F.R. Avaliação de modelos para estimativa de valores diários da radiação solar global com base na temperatura do ar. Revista Brasileira de Agrometeorologia, v.15, 103-108, 2007.

DOORENBOS, J.; KASSAM, A.H. Yield response to water. Rome: FAO, 1979. 193p. (Irrigation and Drainage Paper, 33).

GOLDEMBERG, J. Ethanol for a sustainable energy future. Science, v.315, p.808-810, 2007.

IBGE. Produção agrícola municipal. 2002. Available at: $<$ http://www.ibge.gov.br/home/estatistica/economia/pam/2002/ default.shtm>. Accessed on: 30 Jun. 2008.

IPCC. Climate change 2007: the physical science basis: summary for policymakers. Geneva: IPCC, 2007. 18p. Available at: $<\mathrm{http}$ // www.ipcc.ch/SPM2feb07.pdf>. Accessed on: 2 Apr. 2008.

KEATING, B.A.; ROBERTSON, M.J.; MUCHOW, R.C.; HUTH, N.I. Modelling sugarcane production systems. I. Development and performance of the sugarcane module. Field Crops Research, v.61, p.253-271, 1999.

KHESHGI, H.S.; PRINCE, R.C.; MARLAND, G. The potential of biomass fuels in the context of global climate change: focus on transportation fuels. Annual Review of Energy and the Environment, v.25, p.199-244. 2000. 
KOFFLER, N.F.; DONZELI, P.L. Avaliação dos solos brasileiros para a cultura da cana-de-açúcar. In: PARANHOS, S.B. (Ed.). Cana-de-açúcar: cultivo e utilização. Campinas: Fundação Cargill, 1987. v.2. p.19-41.

LINGLE, S.E. Sugar metabolism during growth and development in sugarcane internodes. Crop Science, v.39, p.480-486, 1999.

LISSON, S.N.; INMAN-BAMBER, N.G.; ROBERTSON, M.J.; KEATING, B.A. The historical and future contribution of crop physiology and modelling research to sugarcane production systems. Field Crops Research, v.92, p.321-335, 2005.

MACEDO, I. de C. A energia da cana-de-açúcar: doze estudos sobre a agroindústria da cana-de-açúcar no Brasil e a sua sustentabilidade. 2.ed. São Paulo: Única, 2007. 231p.

MARJOTTA-MAISTRO, M.C. Ajustes nos mercados de álcool e gasolina no processo de desregulamentação. 2002. 180p. Tese (Doutorado) - Escola Superior de Agricultura Luiz de Queiroz, Piracicaba.

MAULE, R.F.; MAZZA, J.A.; MARTHA JUNIOR, G.B. Produtividade agrícola de cultivares de cana-de-açúcar em diferentes solos e épocas de colheita. Scientia Agricola, v.58, p.295-301, 2001.
MEZA, F.; VARAS, E. Estimation of mean monthly solar global radiation as a function of temperature. Agricultural and Forest Meteorology, v.100, p.231-241, 2000.

MONTEITH, J.L. Climate and the efficiency of crop production in Britain. Philosophical Transactions of the Royal Society of London. Series B, Biological Sciences, v.281, p.277-294, 1977.

MONTEITH, J.L. Solar radiation and productivity in tropical ecosystems. Journal of Applied Ecology, v.9, p.747-766, 1972.

OLIVEIRA, J.B. Solos do Estado de São Paulo: descrição das classes registradas no mapa pedológico. Campinas: Instituto Agronômico, 1999. 112p. (Boletim Científico, 45).

SANTOS, A.I. dos. Setor sucroalcooleiro: conjuntura e perspectivas. Análise Conjuntural, v.27, p.7-8, 2005.

SHIKIDA, P.F.A.; BACHA, C.J.C. Evolução da agroindústria canavieira brasileira de 1975 a 1995 . Revista Brasileira de Economia, v.53, p.69-89, 1999.

SMITH, D.M.; INMAN-BAMBER, N.G.; THORBURN, P.J. Growth and function of the sugarcane root system. Field Crops Research, v.92, p.169-183, 2005.

SNEDECOR, G.; COCHRAN, W.G. Statistical methods. $7^{\text {th }}$ ed. Ames: Iowa State University Press, 1982. 507p.

Received on May 21, 2008 and accepted on October 27, 2008 